\title{
Article \\ Poultry and Wild Birds as a Reservoir of CMY-2 Producing Escherichia coli: The First Large-Scale Study in Greece
}

\author{
Zoi Athanasakopoulou ${ }^{1}$, Katerina Tsilipounidaki ${ }^{2}$, Marina Sofia ${ }^{1}$, Dimitris C. Chatzopoulos ${ }^{1}$, \\ Alexios Giannakopoulos ${ }^{1}$, Ioannis Karakousis ${ }^{3}$, Vassilios Giannakis ${ }^{3}$, Vassiliki Spyrou ${ }^{4}$, Antonia Touloudi ${ }^{1}$, \\ Maria Satra ${ }^{5}$, Dimitrios Galamatis ${ }^{6}$, Vassilis Diamantopoulos ${ }^{7}$, Spyridoula Mpellou ${ }^{8}$, Efthymia Petinaki ${ }^{2}$ and \\ Charalambos Billinis $1,5, *$ (D)
}

1 Faculty of Veterinary Science, University of Thessaly, 43100 Karditsa, Greece; zathanas@uth.gr (Z.A.); msofia@uth.gr (M.S.); dchatzopoulos@uth.gr (D.C.C.); algiannak@uth.gr (A.G.); atoul@uth.gr (A.T.)

2 Faculty of Medicine, University of Thessaly, 41500 Larissa, Greece; tsilipou@uth.gr (K.T.); petinaki@uth.gr (E.P.)

3 Elanco Hellas S.A.C.I., 15231 Athens, Greece; jkarakousis@elanco.gr (I.K.); vgiannakis@elanco.gr (V.G.)

4 Faculty of Animal Science, University of Thessaly, 41110 Larissa, Greece; vasilikispyrou@uth.gr

5 Faculty of Public and Integrated Health, University of Thessaly, 43100 Karditsa, Greece; msatra@uth.gr

6 Hellenic Agricultural Organization DIMITRA (ELGO DIMITRA), 57001 Thessaloniki, Greece; galamatis@elog.gr

7 Directorate of Public Health, Prefecture of Peloponnese, 22132 Tripoli, Greece; diamantopoulos@ppel.gov.gr

check for updates

Citation: Athanasakopoulou, Z; Tsilipounidaki, K.; Sofia, M.; Chatzopoulos, D.C.; Giannakopoulos, A.; Karakousis, I.; Giannakis, V.; Spyrou, V.; Touloudi, A.; Satra, M.; et al. Poultry and Wild Birds as a Reservoir of CMY-2 Producing Escherichia coli: The First Large-Scale Study in Greece. Antibiotics 2021, 10, 235. https://doi.org/10.3390/ antibiotics 10030235

Academic Editor: Piera Anna Marti-no

Received: 14 February 2021 Accepted: 23 February 2021 Published: 26 February 2021

Publisher's Note: MDPI stays neutral with regard to jurisdictional claims in published maps and institutional affiliations.

Copyright: (c) 2021 by the authors. Licensee MDPI, Basel, Switzerland. This article is an open access article distributed under the terms and conditions of the Creative Commons Attribution (CC BY) license (https:/ / creativecommons.org/licenses/by/ $4.0 /)$.
8 Bioefarmoges Eleftheriou LP-Integrated Mosquito Control, 19007 Marathon, Greece; smpellou@bioefarmoges.com

* Correspondence: billinis@uth.gr

Abstract: Resistance mediated by $\beta$-lactamases is a globally spread menace. The aim of the present study was to determine the occurrence of Escherichia coli producing plasmid-encoded AmpC $\beta$ lactamases $(\mathrm{pAmpC})$ in animals. Fecal samples from chickens $(\mathrm{n}=159)$, cattle $(\mathrm{n}=104)$, pigs $(\mathrm{n}=214)$, and various wild bird species $(n=168)$, collected from different Greek regions during 2018-2020, were screened for the presence of $\mathrm{pAmpC}$-encoding genes. Thirteen E. coli displaying resistance to third-generation cephalosporins and a positive AmpC confirmation test were detected. bla $a_{\mathrm{CMY}-2}$ was the sole pAmpC gene identified in 12 chickens' and 1 wild bird (Eurasian magpie) isolates and was in all cases linked to an upstream ISEcp1-like element. The isolates were classified into five different sequence types: ST131, ST117, ST155, ST429, and ST1415. Four chickens' stains were assigned to ST131, while five chickens' strains and the one from the Eurasian magpie belonged to ST117. Seven $\mathrm{pAmpC}$ isolates co-harbored genes conferring resistance to tetracyclines (tet $M$, tet $B$, tet $C$, tet $D$ ), 3 carried sulfonamide resistance genes (sulI and sulII), and 10 displayed mutations in the quinolone resistance-determining regions of gyrA $(\mathrm{S} 83 \mathrm{~L}+\mathrm{D} 87 \mathrm{~N})$ and $\operatorname{parC}(\mathrm{S} 80 \mathrm{I}+\mathrm{E} 84 \mathrm{~V})$. This report provides evidence of $\mathrm{pAmpC}$ dissemination, describing for the first time the presence of CMY-2 in chickens and wild birds from Greece.

Keywords: Escherichia coli; AmpC $\beta$-lactamases; antimicrobial resistance; CMY-2 type; ISEcp1; chickens; wild birds; livestock; Greece

\section{Introduction}

Antimicrobial resistance (AMR) is a globally emergent, constantly evolving threat affecting humans, animals, and the environment, thus today constituting one of the greatest One Health challenges. Bacterial resistance to cephalosporins is mainly mediated by the production of extended-spectrum $\beta$-lactamases (ESBL) and AmpC $\beta$-lactamases. AmpC enzymes confer resistance to $\beta$-lactams, with the exception of fourth-generation cephalosporins and carbapenems, and subsequently render this essential class of antibiotics ineffective [1,2]. The presence of an AmpC combined with loss of outer membrane porins can, notably, further mediate resistance to carbapenems [2,3]. Hence, although 
plasmid-encoded AmpC enzymes (pAmpC) are less prevalent than ESBL in most parts of the world, they may lead to resistance of a broader spectrum, while additionally being harder to detect [2].

The most common pAmpC $\beta$-lactamase reported in Escherichia coli (E. coli) isolates of both human and animal origin globally is CMY-2 [4]. The zoonotic potential of this resistance determinant is illustrated by the detection of $b l a_{\mathrm{CMY}-2}$ on related plasmids and $E$. coli clones in various hosts [5-7]. Insertion sequences, such as ISEcp1, are known to play an important role in the mobilization and thus, the spread of this gene [8,9]. Among animals, poultry have been described as the most frequent $b l a_{\mathrm{CMY}-2}$ carrier that can also act as an important infection source for humans, especially through meat and meat products $[10,11]$. On the contrary, cattle and pigs are less frequently detected to harbor this gene [12]. Alarmingly, the worldwide spread of $\mathrm{pAmpC}$ has additionally been evidenced in wildlife and the environment $[13,14]$. Wild birds play an important role as vectors of AMR and have been suggested as sentinels of circulating resistance genes within a certain geographic region $[15,16]$. Omnivorous, synanthropic birds are more likely to carry and disseminate resistant strains due to their vicinity to human activities and their feeding habits [17]. Despite the well documented role of animals as reservoirs and spreaders of $\mathrm{pAmpC}$, their ability to directly transmit resistant bacteria to humans remains debatable $[10,18]$.

AMR constitutes a serious threat for Greek public health. According to the surveillance report of the European Centre for Disease Prevention and Control (ECDC), Greece is classified among the countries confronting AMR the most [19], while native consumption of anti-infectives for systematic use is the highest in Europe [20]. pAmpC variants of the CMY family seem to circulate among human isolates in the country [21], while there is evidence to support that this case applies for companion animal isolates as well $[22,23]$. In livestock and poultry, the presence of $\mathrm{pAmpC}$ strains has also been ascertained [12,24]. However, there is hitherto paucity of knowledge regarding the molecular characteristics of $\mathrm{pAmpC}$ strains isolated from farmed and wild animals, as well as their possible relationship to human hosts.

Considering the emergence of AMR and the lack of detailed data in Greece, this study aimed to evaluate the presence of $\mathrm{pAmpC}$-producing $E$. coli from poultry, cattle, pigs, and wild birds, to detect the responsible pAmpC genes and to identify the E. coli sequence types (ST). All pAmpC-producing E. coli isolates that were phenotypically resistant to antimicrobials other than $\beta$-lactams, including tetracyclines, sulfonamides, and quinolones, were further tested for the respective resistance determinants.

\section{Results}

\subsection{Detection of $p A m p C$ Genes in E. coli Isolates}

Among the 646 animal samples, 168 were derived from wild bird species, 104 from cattle, 214 from pigs, and the remaining 159 from chickens. A total of 13 E. coli, 12 from chickens $(12 / 159,7.5 \%)$ and 1 from a Eurasian magpie (1/168, 0.6\%), was found to be resistant to third-generation cephalosporins (3GC) and had a positive $\mathrm{pAmpC}$-confirmation test. Molecular screening for $\mathrm{pAmpC}$ encoding genes revealed that all isolates carried the CMY-2 type and no other $\mathrm{pAmpC}$ gene type was detected in any isolate.

All strains were positive in the PCR targeting ISEcp 1-CMY, and sequencing analysis confirmed that $b l a_{\mathrm{CMY}-2}$ genes were linked to an upstream ISEcp1-like element.

\subsection{Molecular Typing}

Molecular typing of the 13 isolates classified them into five different STs. ST117 E. coli was recovered from the wild bird as well as from five chickens. Among the remaining seven chicken strains, four were assigned to ST131 and three were identified as either ST155 or ST429 or ST1415. 


\subsection{Detection of Additional Resistance Genes}

According to susceptibility testing, 12 of the 13 CMY-2-positive E. coli strains, including the one from the wild bird, exhibited concurrent resistance to at least three classes of antibiotics. ESBL production, by phenotypic testing, was not observed for any strain. Six strains from chickens and the one from a wild bird exhibited resistance to tetracycline $\left(\mathrm{TET}^{\mathrm{R}}\right)$. Out of the seven tetracycline-resistant strains, six carried tet $M$, while co-occurrence of $t e t B$, tet $C$, and tet $D$ was observed in the remaining one. Resistance to sulphonamides was expressed in two strains from chickens as well as in the one from the Eurasian magpie, which all harbored both sulI and sulII genes. Ten strains showed resistance to quinolones and fluoroquinolones $\left(\mathrm{QN} / \mathrm{FQN}^{\mathrm{R}}\right)$, although none carried $q n r A, q n r B$, or $q n r S$. Sequencing analysis of the QRDRs of gyrA and parC, performed on the resistant isolates, revealed that all strains displayed a mutation of serine- 83 to leucine and a mutation of aspartic acid-87 to asparagine in $g y r A$. In addition, ST131 strains also had alterations of serine- 80 to isoleucine and glutamic acid-84 to valine in the QRDR of parC.

The antimicrobial resistance and molecular typing results of the strains are summarized in Table 1.

Table 1. Characteristics of the plasmid-encoded AmpC $\beta$-lactamase (pAmpC)-producing E. coli isolates.

\begin{tabular}{|c|c|c|c|c|c|}
\hline \multirow[b]{2}{*}{ Isolate } & \multirow[b]{2}{*}{ Host } & \multirow[b]{2}{*}{ Sequence Type } & \multicolumn{3}{|c|}{ Resistance Profile } \\
\hline & & & Phenotype & $\begin{array}{c}\text { Resistance } \\
\text { Determinants }\end{array}$ & $\begin{array}{l}\text { Mutations } \\
(\text { gyrA/parC) }\end{array}$ \\
\hline C46 & Chicken & ST429 & $\begin{array}{c}\text { AMP, AMC, TZP, CEX, CF, CEF, CFIX, } \\
\text { CTX, CAZ, CTRX }\end{array}$ & $b l a_{\mathrm{CMY}-2}$ & - \\
\hline $\mathrm{C} 70$ & Chicken & ST131 & $\begin{array}{c}\text { AMP, AMC, TZP, CEX, CF, CEF, CFIX, } \\
\text { CTX, CAZ, CTRX, FLU }\end{array}$ & $b l a_{\mathrm{CMY}-2}$ & $\mathrm{~S} 83 \mathrm{~L}+\mathrm{D} 87 \mathrm{~N} / \mathrm{S} 80 \mathrm{I}+\mathrm{E} 84 \mathrm{~V}$ \\
\hline C79 & Chicken & ST131 & $\begin{array}{l}\text { AMP, AMC, TZP, CEX, CF, CEF, CFIX, } \\
\text { CTX, CAZ, CTRX, FLU }\end{array}$ & $b l a_{\mathrm{CMY}-2}$ & $\mathrm{~S} 83 \mathrm{~L}+\mathrm{D} 87 \mathrm{~N} / \mathrm{S} 80 \mathrm{I}+\mathrm{E} 84 \mathrm{~V}$ \\
\hline C83 & Chicken & ST117 & $\begin{array}{l}\text { AMP, AMC, TZP, CEX, CF, CFIX, } \\
\text { CAZ, CTRX, FLU, TET, SXT }\end{array}$ & $\begin{array}{c}\text { bla } a_{\mathrm{CMY}-2} \\
\text { tet } \mathrm{M}, \text { sulI, sulII }\end{array}$ & S83L+D87N \\
\hline C88 & Chicken & ST117 & $\begin{array}{l}\text { AMP, AMC, TZP, CEX, CF, CFIX, } \\
\text { CAZ, CTRX, FLU, TET }\end{array}$ & $b l a_{\mathrm{CMY}-2}$, tet $\mathrm{M}$ & S83L+D87N \\
\hline C103 & Chicken & ST117 & $\begin{array}{l}\text { AMP, AMC, TZP, CEX, CF, CFIX, } \\
\text { CAZ, CTRX, FLU, TET }\end{array}$ & $b l a_{\mathrm{CMY}-2}$, tet $\mathrm{M}$ & S83L+D87N \\
\hline C117 & Chicken & ST117 & $\begin{array}{l}\text { AMP, AMC, TZP, CEX, CF, CFIX, } \\
\text { CAZ, CTRX, FLU, TET }\end{array}$ & $b l a_{\mathrm{CMY}-2,}$ tet $\mathrm{M}$ & S83L+D87N \\
\hline C119 & Chicken & ST117 & $\begin{array}{l}\text { AMP, AMC, TZP, CEX, CF, CFIX, } \\
\text { CAZ, CTRX, FLU, TET, SXT }\end{array}$ & $\begin{array}{l}\text { bla } a_{\mathrm{CMY}-2,} \\
\text { tet } \mathrm{M}, \text { sulI, sulII }\end{array}$ & S83L+D87N \\
\hline C136 & Chicken & ST131 & $\begin{array}{c}\text { AMP, AMC, TZP, CEX, CF, CEF, CFIX, } \\
\text { CTX, CAZ, CTRX, FLU }\end{array}$ & $b l a_{\mathrm{CMY}-2}$ & $\mathrm{~S} 83 \mathrm{~L}+\mathrm{D} 87 \mathrm{~N} / \mathrm{S} 80 \mathrm{I}+\mathrm{E} 84 \mathrm{~V}$ \\
\hline C138 & Chicken & ST1415 & $\begin{array}{c}\text { AMP, AMC, TZP, CEX, CF, CEF, CFIX, } \\
\text { CTX, CAZ, CTRX, TET }\end{array}$ & $\begin{array}{l}\text { bla }_{\mathrm{CMY}-2}, \text { tet } B \\
\text { tet } \mathrm{C}, \text { tet } D\end{array}$ & - \\
\hline C147 & Chicken & ST131 & $\begin{array}{l}\text { AMP, AMC, TZP, CEX, CF, CEF, CFIX, } \\
\text { CTX, CAZ, CTRX, FLU }\end{array}$ & $b l a_{\mathrm{CMY}-2}$ & S83L+D87N/S80I+E84V \\
\hline C156 & Chicken & ST155 & $\begin{array}{c}\text { AMP, AMC, TZP, CEX, CF, CEF, CFIX, } \\
\text { CTX, CAZ, CTRX }\end{array}$ & $b l a_{\mathrm{CMY}-2}$ & - \\
\hline WB105 & $\begin{array}{l}\text { Eurasian } \\
\text { magpie } \\
\text { (Pica pica) }\end{array}$ & ST117 & $\begin{array}{l}\text { AMP, AMC, TZP, CEX, CF, CEF, CFIX, } \\
\text { CTX, CAZ, CTRX, FLU, TET, SXT }\end{array}$ & $\begin{array}{l}\text { bla } \mathrm{CMY-2}, \text { tetM, } \\
\text { sulI, sulII }\end{array}$ & S83L+D87N \\
\hline
\end{tabular}

\section{Discussion}

In this study, pAmpC-producing E. coli strains were detected in $7.5 \%$ of chickens and $0.6 \%$ of wild birds, while they were not identified in cattle and pig samples. The higher frequency of $\mathrm{pAmpC}$ isolates among poultry, compared to other species, was in accordance 
with previously published data $[10,12]$. Their absence in cattle and pigs was expected, considering the European Union Summary Report on Antimicrobial Resistance for the years 2017 and 2018 that described low detection among fattening pigs and zero occurrence in bovine meat from Greece [12].

To the best of our knowledge, this is the first time that CMY-2 type is identified from $E$. coli isolates of farmed chickens in Greece and $b l a_{\mathrm{CMY}-2}$ was the sole $\mathrm{pAmpC}$ gene detected, which is in agreement with previous studies [25-27]. Carriage was relatively low $(7.5 \%)$, compared to recent reports from neighboring countries such as Turkey [28], Romania [29], and Italy [25]. Our finding may be indicative of CMY-2 type low occurrence in Greek poultry but, given the lack of previous screening studies, further investigations would be helpful to verify the aforementioned low prevalence. Considering the European prohibition of cephalosporins' use in poultry, the emergence of ESBL/pAmpC-producing Enterobacteriaceae may be attributed to the treatment of eggs and/or one-day-old chickens in grandparent and parent flocks, along with the current management practices [30,31]. It has been shown that broilers can maintain pAmpC E. coli imported to the flock via one-dayold chicks or breeding animals even in the absence of selective antibiotic pressure $[32,33]$. This can be reflected in poultry meat, raising concern about the zoonotic capacity of pAmpC isolates.

We additionally detected a pAmpC-producing E. coli harbored by a Eurasian magpie (Pica pica) and, as far as we know, this is the first identification of CMY-2 type gene in a wild bird species from Greece. CMY-2 prevails among pAmpC E. coli isolates of corvids from The Czech Republic, Poland [34], Austria [16], Canada [17], and The USA [35,36], and of aquatic birds from The Netherlands [13], Spain [37], and Florida, USA [38]. We found a relatively low $\mathrm{pAmpC}$ carriage $(0.6 \%)$ and our results are comparable with those of Alcala et al. [37] who reported 1.0\% detection in Spain. Although higher pAmpC carriage has been published previously, varying from $3.4 \%$ in The Netherlands [13] to $26.9 \%$ in Florida [38], the low detection reported in our study could be attributed to the wide variety of the sampled wild bird species. Sampling and testing were performed, for screening purposes, not only in corvids and aquatic birds, but additionally in "low-risk" wild bird species, which are neither migratory nor omnivorous or aquatic-associated. Eurasian magpie is an omnivore and opportunistic scavenger, highly adapted to human environments and one of the most abundant corvids in Europe. Its diet and ecology, frequently interacting with humans and domestic animals, could explain the detection of a pAmpC-producing strain, as previously described for corvid populations [17]. Eurasian magpies are also known to form large communal roosts outside the breeding season, which could contribute to CMY-2 persistence and dissemination by bird-to-bird transmission during winter.

ISEcp 1 was found in the upstream region of $b l a_{\mathrm{CMY}-2}$ in all our isolates. Co-existence of ISEcp1 with ESBL/pAmpC genes in E. coli strains is well documented and has been associated with their efficient capture, expression, and mobilization $[39,40]$. Being responsible for bla ${ }_{\mathrm{CMY}-2}$ transposition to different plasmids, ISEcp1 probably has an important role in the dissemination of this beta-lactamase and subsequently the enhancement of its zoonotic potential [41].

MLST analysis demonstrated that the CMY-2-producing E. coli isolates of chickens were distributed in five different STs. Four chickens' strains were assigned to ST131, a clone with a worldwide distribution that has contributed to the dissemination of the ubiquitous ESBL variant CTX-M-15, as well as other resistance genes [42,43]. This finding highlights the potential of acquired AmpC enzymes to arise as an important zoonotic issue. Further supporting this claim, we also detected $b l a_{\mathrm{CMY}-2}$ type in a chicken $E$. coli ST155, a clone commonly reported in poultry but additionally significant for public health [44,45]. On the contrary, ST429 that was detected to express CMY-2, is a predominant avian pathogenic lineage, related only to incidental human infections [46,47]. In Greece, CMY-2-producing E. coli ST429 has previously been isolated from a healthy household dog [23], which could imply inter-species circulation of the clone in the country. The CMY-2 type-producing $E$. coli isolated from the Eurasian magpie (Pica pica) belonged to ST117, previously reported in 
corvids both in Europe and in Canada [17,34]. Five chickens' isolates were also assigned to this clinically important multiresistant ST, suggesting possible strain transmission among different animal hosts in the country. Detection of ST117 in poultry and a wild bird raises concern, given its frequent association to hospital-based and community-acquired human infections worldwide [48-50]. Finally, an E. coli of chicken origin was classified as ST1415, a rather rare ST that, to our knowledge, has not been previously related to CMY-2.

Tetracycline resistance genes were identified in 6 out of the 12 CMY-2-producing poultry isolates, as well as in the Eurasian magpie isolate. Five chickens' strains carried tet $M$, while tet $B$, tet $C$, and tet $D$ were detected in the remaining one. The high frequency of tetracycline resistance among chicken $\mathrm{pAmpC}$-producing isolates probably depicts the widespread use of this antibiotic in poultry husbandry all over the world [51]. Cooccurrence of bla $a_{\mathrm{CMY}-2}$ and tet genes has formerly been reported in E. coli isolates from chicken carcasses in South Brazil [41], retail chicken meat in Canada [52], as well as in avian pathogenic E. coli from septicemic broilers in Egypt [53]. Additionally, the Eurasian magpie CMY-2 type-positive isolate displayed tetracycline resistance mediated by tet $M$ and our finding complies with Sen et al. [35], who detected co-occurrence of $t e t M$ and $b l a_{\mathrm{CMY}-2}$ in crow isolates.

Resistance to sulfonamides was detected in three strains, two from chickens and the one from the Eurasian magpie, which all harbored sulI and sulII sulfonamide resistance genes. In the past, sulfonamides were extensively used in traditional poultry production systems in order to achieve higher population densities and increased production. Overconsumption of this antimicrobial class resulted in the development of high resistance rates, reducing significantly its role in the poultry production nowadays [54,55]. As far as the Eurasian magpie isolate is concerned, resistance against chemically synthesized antibiotic classes such as sulphonamides has been reported in wild fauna, even though these antimicrobials are not expected to be widespread in the environment [56]. Co-occurrence of ESBL/pAmpC and sulfonamide resistance determinants on the same plasmid could probably explain the latter's detection in the wild bird isolate [57].

Quinolone resistance was also reported in CMY-2 E. coli strains from nine chickens and the Eurasian magpie. Mutations were responsible for the $\mathrm{QN} / \mathrm{FQN}^{\mathrm{R}}$ phenotype and all isolates possessed the same amino acid substitution pattern in gyrA gene. ST131 E. coli possessed the S83L + D87N in gyr A combined with S80I + E84V in parC. Notably, the same mutations have been found in a collection of ST131 E. coli isolated from humans in Central Greece [58]. That study suggested that fluoroquinolone resistance in humans could be related to the use of these antimicrobials in the veterinary practice and the poultry production of the area. Our results verify that this specific substitutional pattern exists in $E$. coli strains of poultry origin. However, no isolate in our study co-harbored bla ${ }_{\mathrm{CMY}-2}$ and plasmid mediated quinolone resistance (PMQR) genes, as has previously been described for ESBL/pAmpC-producing E. coli of poultry and wild bird origin $[13,59,60]$.

\section{Materials and Methods}

\subsection{Sample Collection}

During 2018-2020, a total of 646 non duplicated fecal samples of clinically healthy animals were collected from different regions of Greece. In particular, 159 stool samples were collected from chickens, 104 from cattle, 214 from pigs, and 168 from thirty different wild bird species (Table 2). Samples were obtained by inserting a sterile cotton swab (Transwab ${ }^{\circledR}$ Amies, UK) into the rectum or the cloaca and gently rotating the tip against the mucosa.

Regarding sampling of different wild bird species, Larsen and Australian type traps as well as modified bird catching nets were used, located in a variety of habitats. The sampling site of each wild bird was recorded using handheld Global Positioning System (GPS) units. All wild birds were released immediately following sampling, according to the prerequisites of the Greek Legislation. 
Swabs were transported under refrigeration and laboratory analysis was initiated $24-48 \mathrm{~h}$ from the samples' collection day.

Table 2. Number of samples per wild bird species included in the study.

\begin{tabular}{|c|c|c|}
\hline Common Name & Scientific Name & Number of Samples \\
\hline Common blackbird & Turdus merula & 4 \\
\hline Common buzzard & Buteo buteo & 5 \\
\hline Common pheasant & Phasianus colchicus & 7 \\
\hline Common starling & Sturnus vulgaris) & 9 \\
\hline Common swift & Apus apus & 1 \\
\hline Common whitethroat & Sylvia communis & 2 \\
\hline Common wood pigeon & Columba palumbus & 3 \\
\hline Domestic Muscovy duck & Cairina moschata domestica & 1 \\
\hline Domestic goose & Anser cygnoides domesticus & 1 \\
\hline Eurasian collared dove & Streptopelia decaocto & 2 \\
\hline Eurasian eagle-owl & Bubo bubo & 3 \\
\hline European goldfinch & Carduelis carduelis & 6 \\
\hline Eurasian scops owl & Otus scops & 1 \\
\hline Eurasian tree sparrow & Passer montanus & 9 \\
\hline Eurasian woodcock & Scolopax rusticola & 11 \\
\hline Golden pheasant & Chrysolophus pictus & 2 \\
\hline Great tit & Parus major & 5 \\
\hline House sparrow & Passer domesticus & 14 \\
\hline Lesser kestrel & Falco naumanni & 1 \\
\hline Leaf warbler & Phylloscopus spp. & 1 \\
\hline Little owl & Athene noctua & 2 \\
\hline Long-eared owl & Asio otus & 2 \\
\hline Eurasian Magpie & Pica pica & 52 \\
\hline Mallard & Anas platyrhynchos & 3 \\
\hline Redwing & Turdus iliacus & 1 \\
\hline Rock partridge & Alectoris graeca & 3 \\
\hline Sardinian warbler & Sylvia melanocephala & 1 \\
\hline Short-toed snake eagle & Circaetus gallicus & 1 \\
\hline Song thrush & Turdus philomelos & 14 \\
\hline Yellow-legged gull & Larus michahellis & 1 \\
\hline
\end{tabular}

4.2. Isolation, Identification and Antimicrobial Susceptibility Testing of pAmpC-producing E. coli

For the isolation of $\mathrm{pAmpC}$-producing Enterobacterales, swabs were directly streaked on ESBL selective media (CHROMID ${ }^{\circledR}$ ESBL, BioMérieux, Marcy l'Etoile, France) (a medium able to detect both ESBLs and high-level expressed AmpC cephalosporinases) and then the plates were incubated aerobically at $37^{\circ} \mathrm{C}$ for $48 \mathrm{~h}$ in order to increase sensitivity [61]. Each morphologically different pink colony, corresponding to E. coli grown on the plates, was sub-cultured on MacConkey agar. Identification of the isolated bacteria and antimicrobial susceptibility testing were carried out using the automated Vitek-2 system (BioMérieux, Marcy l'Etoile, France), according to the manufacturer's instructions. The antimicrobial agents tested, using the AST-GN96 card, were ampicillin, amoxicillin/clavulanic acid, ticar- 
cillin/clavulanic acid, cefalexin, cefalotin, cefoperazone, ceftiofur, cefquinome, imipenem, gentamicin, neomycin, flumequine, enrofloxacin, marbofloxacin, tetracycline, florfenicol, polymyxin B, and trimethoprim/sulfamethoxazole. Interpretation of the antimicrobial susceptibility testing was performed automatically by the Vitek-2 software (BioMérieux, system version 8.02). Susceptibility to piperacillin/tazobactam, cefixime, cefotaxime, ceftazidime, and ceftriaxone was also tested by Etest, according to EUCAST guidelines [62].

All E. coli isolates that were resistant to 3GC were further tested for phenotypic AmpC production using Etest strips containing cefotetan and cefotetan plus cloxacillin (Liofilchem). Isolates that had a ratio cefotetan/cefotetan + cloxacillin $\geq 8$ were selected for molecular detection of $\mathrm{AmpC}$ genes and molecular typing. Additionally, these isolates were phenotypically screened for ESBL production using Etest strips containing cefotaxime + /- clavulanic acid and Ceftazidime +/- clavulanic acid (Liofilchem). An MIC ratio $\geq 8$ or the presence of a deformed ellipse were considered indicative of ESBL production.

\subsection{DNA Extraction of the AmpC-Producing E.coli}

Bacterial DNA was extracted from overnight cultures of the selected isolates using the PureLink ${ }^{\mathrm{TM}}$ Genomic DNA Mini Kit (Invitrogen, Darmstadt, Germany), according to the manufacturer's instructions for Gram-negative bacteria.

\subsection{Molecular Confirmation of PAmpC Production and Screening of Insertion Sequence}

In all isolates, simplex PCRs were performed for amplification of genes for the most common types of plasmid mediated AmpC $\beta$-lactamases using the primers described by Pérez-Pérez and Hanson [63] (Table 3). Post-amplification products were visualized on $2 \%$ agarose gel electrophoresis. The PCR products were purified and were analyzed by sequencing (3730xl DNA Analyzer, Applied Biosystems).

Table 3. Primer sequences, amplicon sizes, and optimal annealing temperatures of each simplex PCR performed for the amplification of $\mathrm{pAmpC}$ and other resistance genes.

\begin{tabular}{|c|c|c|c|c|}
\hline Target & Primer Sequence $\left(5^{\prime}-3^{\prime}\right)$ & Amplicon Size (bp) & $\begin{array}{c}\text { Annealing } \\
\text { Temperature }\left({ }^{\circ} \mathrm{C}\right)\end{array}$ & Reference \\
\hline $\begin{array}{c}\text { MOX } \\
\text { (MOX-1, MOX-2, CMY-1, } \\
\text { CMY-8 to CMY-11) }\end{array}$ & $\begin{array}{l}\text { F: GCTGCTCAAGGAGCACAGGAT } \\
\text { R:CACATTGACATAGGTGTGGTGC }\end{array}$ & 520 & 55 & [63] \\
\hline $\begin{array}{c}\text { CIT } \\
\text { (LAT-1 to LAT-4, } \\
\text { CMY-2 to CMY-7, BIL-1) }\end{array}$ & $\begin{array}{l}\text { F: TGGCCAGAACTGACAGGCAAA } \\
\text { R: TTTCTCCTGAACGTGGCTGGC }\end{array}$ & 462 & 55 & {$[63]$} \\
\hline $\begin{array}{c}\text { DHA } \\
\text { (DHA-1, DHA-2) }\end{array}$ & $\begin{array}{l}\text { F: AACTTTCACAGGTGTGCTGGGT } \\
\text { R: CCGTACGCATACTGGCTTTGC }\end{array}$ & 405 & 56 & {$[63]$} \\
\hline ACC & $\begin{array}{l}\text { F: AACAGCCTCAGCAGCCGGTTA } \\
\text { R: TTCGCCGCAATCATCCCTAGC }\end{array}$ & 346 & 55 & [63] \\
\hline $\begin{array}{c}\text { EBC } \\
(\text { MIR-1T ACT-1) }\end{array}$ & $\begin{array}{l}\text { F: TCGGTAAAGCCGATGTTGCGG } \\
\text { R: CTTCCACTGCGGCTGCCAGTT }\end{array}$ & 302 & 58 & [63] \\
\hline $\begin{array}{c}\text { FOX } \\
\text { (FOX-1 to FOX-5b) }\end{array}$ & $\begin{array}{l}\text { F:AACATGGGGTATCAGGGAGATG } \\
\text { R: CAAAGCGCGTAACCGGATTGG }\end{array}$ & 190 & 55 & [63] \\
\hline tet $A$ & $\begin{array}{l}\text { F: GCCTTTCCTTTGGGTTCTCT } \\
\text { R: TGTCCGACAAGTTGCATGAT }\end{array}$ & 402 & 55 & [64] \\
\hline tetB & $\begin{array}{l}\text { F: CACCACCAGCCAATAAAATT } \\
\text { R: TTTATTTAAAACGATGCCCA }\end{array}$ & 319 & 52 & This study \\
\hline tetC & $\begin{array}{l}\text { F: TCACTGGTTAACTCAGCACG } \\
\text { R: TCAAGTTCATTCCAACCAAT }\end{array}$ & 319 & 52 & This study \\
\hline tetD & $\begin{array}{l}\text { F: CTCCAATTCCCATAATTTAT } \\
\text { R: ATCAAAATAAAGCTAATAAC }\end{array}$ & 379 & 52 & This study \\
\hline tetM & $\begin{array}{l}\text { F: TTATCAACGGTTTATCAGG } \\
\text { R: CGTATATATGCAAGACG }\end{array}$ & 398 & 57 & This study \\
\hline$q n r A$ & $\begin{array}{l}\text { F: AGAGGATTTCTCACGCCAGG } \\
\text { R: CCAGGCACAGATCTTGAC }\end{array}$ & 580 & 55 & [58] \\
\hline$q n r B$ & $\begin{array}{l}\text { F: GGGTATGGATATTATTGATAAAG } \\
\text { R: CTAATCCGGCAGCACTATTA }\end{array}$ & 264 & 55 & [58] \\
\hline
\end{tabular}


Table 3. Cont.

\begin{tabular}{|c|c|c|c|c|}
\hline Target & Primer Sequence $\left(5^{\prime}-3^{\prime}\right)$ & Amplicon Size (bp) & $\begin{array}{c}\text { Annealing } \\
\text { Temperature }\left({ }^{\circ} \mathrm{C}\right)\end{array}$ & Reference \\
\hline$q n r S$ & $\begin{array}{l}\text { F: GCAAGTTCATTGAACAGGGT } \\
\text { R: TCTAAACCGTCGAGTTCGGC }\end{array}$ & 428 & 55 & [58] \\
\hline gyrA & $\begin{array}{l}\text { F: TTAATGATTGCCGCCGTCGG } \\
\text { R: TACACCGGTCAACATTGAGG }\end{array}$ & 648 & 54 & [58] \\
\hline $\operatorname{parC}$ & $\begin{array}{l}\text { F: GTGGTGCCGTTAAGCAAA } \\
\text { R: AAACCTGTTCAGCGCCGCATT }\end{array}$ & 395 & 55 & [58] \\
\hline sulI & $\begin{array}{l}\text { F: ACG AGA TTG TGC GGT TCT TC } \\
\text { R: GGT TTC CGA GAT GGT GAT TG }\end{array}$ & 347 & 55 & [64] \\
\hline sulII & $\begin{array}{l}\text { F: CCG TCT CGC TCG ACA GTT AT } \\
\text { R: GTG TGT GCG GAT GAA GTC AG }\end{array}$ & 506 & 55 & [64] \\
\hline ISEcp1-CMY & $\begin{array}{l}\text { F- AAAAATGATTGAAAGGTGGT } \\
\text { R- TTTCTCCTGAACGTGGCTGGC }\end{array}$ & 546 & 52 & [41] \\
\hline
\end{tabular}

The presence of ISEc 1 insertion element upstream of the $b l a_{\mathrm{CMY}-2}$ was investigated by $\mathrm{PCR}$, using a forward primer targeting the ISE $c$ 1 element and a reverse primer targeting the $b l a_{\mathrm{CMY}}$, as described previously [41] (Table 3).

\subsection{Molecular Typing of Isolates}

Molecular typing of isolates was based on Multilocus Sequence Typing (MLST) in which amplification of seven gene loci $(a d k, f u m C, g y r B, i c d, m d h, p u r A, r e c A)$ was performed by PCR (Table 3). PCR products were purified using PureLink ${ }^{\mathrm{TM}}$ PCR Purification Kit (Thermo Fisher Scientific), according to the manufacturer's instructions. Purified products were sequenced (3730xl DNA Analyzer, Applied Biosystems) and analysis of the alleles was conducted using an online available database (https:/ / pubmlst.org/bigsdb?db=pubmlst_ ecoli_achtman_seqdef) (accessed date: 5 February 2021).

\subsection{Molecular Detection of Additional Resistance Genes}

Strains in which the presence of a $\mathrm{pAmpC}$ gene was confirmed and were phenotypically resistant to tetracyclines, sulfonamides, and/or quinolones were additionally tested for the respective resistance genes. In detail, genes conferring resistance to tetracycline (tet $A$, tet $B$, tetC, tet $D$, tet $M$ ), to sulfonamides (sulI, sulII), and the PMQR determinants (qnrA, $q n r B, q n r S)$ were investigated by PCR. Quinolone-resistant isolates were also screened for mutations in the quinolone resistance-determining regions (QRDRs) of gyrA and parC by PCR and sequencing of the amplicons was performed (3730xl DNA Analyzer, Applied Biosystems) (Table 3).

\section{Conclusions}

In this study, we investigated, for the first time, the occurrence of pAmpC-producing E. coli from various hosts in Greece. Chicken and wild bird strains harbored bla $a_{\mathrm{CMY}-2}$ type in a low prevalence, while pAmpC were not detected in cattle and pigs. ST117 and ST131 were the predominant circulating CMY-2 E. coli clones. Tetracycline, sulfonamide, and quinolone resistance were also identified in the CMY-2 strains, revealing the presence of tet genes, sul genes, and of mutations in the QRDRs, respectively.

Author Contributions: Conceptualization, Z.A., K.T., V.S., E.P., and C.B.; methodology, Z.A., K.T., M.S. (Marina Sofia), D.C.C., A.G., I.K., V.G., V.S., E.P., and C.B.; validation, Z.A., E.P., and C.B.; formal analysis, Z.A. and K.T.; investigation, Z.A., K.T., M.S. (Marina Sofia), D.C.C., A.T., and M.S. (Maria Satra); resources, A.G., I.K., V.G., D.G., V.D., and S.M.; data curation, Z.A., K.T., M.S., D.C.C., A.T., and M.S. (Maria Satra); writing—original draft preparation, Z.A., K.T., and M.S.; writing—review and editing, Z.A., V.S., E.P., and C.B.; supervision, V.S., E.P., and C.B.; project administration, V.S., E.P., and C.B.; funding acquisition, M.S. (Marina Sofia), D.C.C., A.G., I.K., V.G., V.S., E.P., and C.B. All authors have read and agreed to the published version of the manuscript. 
Funding: This work has been co-funded by the European Union and the General Secretariat for Research and Innovation, Ministry of Development \& Investments, under the project «Novel technologies for surveillance and characterization of Extended-spectrum $\beta$-lactamase and Carbapenemase producing Enterobacteriaceae, in humans and animals (CARBATECH)» T2DGE-0944, of the Bilateral S\&T Cooperation Program Greece-Germany 2017. This support is gratefully acknowledged.

Institutional Review Board Statement: All samples were obtained by noninvasive rectal or cloacal swabs and no research on animals, as defined in the EU Ethics for Researchers document (European Commission, 2013, Ethics for Researchers-Facilitating Research Excellence in FP7, Luxembourg: Office for Official Publications of the European Communities, ISBN 978-92-79-28854-8), was carried out for this study. Official permissions for capturing and sampling crows, migratory and epidemic wild birds were provided by the Hellenic Ministry of Environment and Energy (159469/1920/217-2017), (181997/1000/10-5-2019). Capturing, handling and sampling wild birds complied with European and national legislation.

Data Availability Statement: Most data for this study are presented within the manuscript. The remaining data are available on request from the corresponding author. The data are not publicly available as they are part of the PhD thesis of the first author, which has not yet been examined, approved and uploaded in the official depository of $\mathrm{PhD}$ theses from Greek Universities.

Conflicts of Interest: The authors declare no conflict of interest.

\section{References}

1. Critically Important Antimicrobials for Human Medicine, 6th ed.; World Health Organization: Geneva, Switzerland, 2019.

2. Jacoby, G.A. AmpC B-Lactamases. Clin. Microbiol. Rev. 2009, 22, 161-182. [CrossRef]

3. Mammeri, H.; Guillon, H.; Eb, F.; Nordmann, P. Phenotypic and Biochemical Comparison of the Carbapenem-Hydrolyzing Activities of Five Plasmid-Borne AmpC $\beta$-Lactamases. Antimicrob. Agents Chemother. 2010, 54, 4556-4560. [CrossRef]

4. Ewers, C.; Bethe, A.; Semmler, T.; Guenther, S.; Wieler, L. Extended-spectrum $\beta$-lactamase-producing and AmpC-producing Escherichia coli from livestock and companion animals, and their putative impact on public health: A global perspective. Clin. Microbiol. Infect. 2012, 18, 646-655. [CrossRef] [PubMed]

5. Pietsch, M.; Irrgang, A.; Roschanski, N.; Michael, G.B.; Hamprecht, A.; Rieber, H.; Käsbohrer, A.; Schwarz, S.; Rösler, U. Whole genome analyses of CMY-2-producing Escherichia coli isolates from humans, animals and food in Germany. BMC Genom. 2018, 19, 601. [CrossRef]

6. Hansen, K.H.; Bortolaia, V.; Nielsen, C.A.; Nielsen, J.B.; Schønning, K.; Agersø, Y.; Guardabassi, L. Host-Specific Patterns of Genetic Diversity among IncI1-I $\gamma$ and IncK Plasmids Encoding CMY-2 $\beta$-Lactamase in Escherichia coli Isolates from Humans, Poultry Meat, Poultry, and Dogs in Denmark. Appl. Environ. Microbiol. 2016, 82, 4705-4714. [CrossRef]

7. Seiffert, S.N.; Carattoli, A.; Schwendener, S.; Collaud, A.; Endimiani, A.; Perreten, V. Plasmids Carrying blaCMY -2/4 in Escherichia coli from Poultry, Poultry Meat, and Humans Belong to a Novel IncK Subgroup Designated IncK2. Front. Microbiol. 2017,8 , 407. [CrossRef] [PubMed]

8. Toleman, M.A.; Walsh, T.R. Combinatorial events of insertion sequences and ICE in Gram-negative bacteria. FEMS Microbiol. Rev. 2011, 35, 912-935. [CrossRef]

9. Verdet, C.; Gautier, V.; Chachaty, E.; Ronco, E.; Hidri, N.; Decré, D.; Arlet, G. Genetic Context of Plasmid-Carried blaCMY-2-Like Genes in Enterobacteriaceae. Antimicrob. Agents Chemother. 2009, 53, 4002-4006. [CrossRef] [PubMed]

10. Madec, J.-Y.; Haenni, M.; Nordmann, P.; Poirel, L. Extended-spectrum $\beta$-lactamase/AmpC- and carbapenemase-producing Enterobacteriaceae in animals: A threat for humans? Clin. Microbiol. Infect. 2017, 23, 826-833. [CrossRef] [PubMed]

11. Berg, E.; Wester, A.; Ahrenfeldt, J.; Mo, S.; Slettemeås, J.; Steinbakk, M.; Samuelsen, Ø.; Grude, N.; Simonsen, G.; Løhr, I.; et al. Norwegian patients and retail chicken meat share cephalosporin-resistant Escherichia coli and IncK/ bla CMY-2 resistance plasmids. Clin. Microbiol. Infect. 2017, 23, 407.e9-407.e15. [CrossRef]

12. The European Union Summary Report on Antimicrobial Resistance in Zoonotic and Indicator Bacteria from Humans, Ani-mals and Food in 2017/2018; Wiley-Blackwell Publishing Ltd.: Hoboken, NJ, USA, 2020; Volume 18.

13. Veldman, K.; van Tulden, P.; Kant, A.; Testerink, J.; Mevius, D. Characteristics of Cefotaxime-Resistant Escherichia coli from Wild Birds in The Netherlands. Appl. Environ. Microbiol. 2013, 79, 7556-7561. [CrossRef]

14. Zhang, A.; Call, D.R.; Besser, T.E.; Liu, J.; Jones, L.; Wang, H.; Davis, M.A. $\beta$-lactam resistance genes in bacteriophage and bacterial DNA from wastewater, river water, and irrigation water in Washington State. Water Res. 2019, 161, 335-340. [CrossRef]

15. Bonnedahl, J.; Järhult, J.D. Antibiotic resistance in wild birds. Upsala J. Med. Sci. 2014, 119, 113-116. [CrossRef] [PubMed]

16. Loncaric, I.; Stalder, G.L.; Mehinagic, K.; Rosengarten, R.; Hoelzl, F.; Knauer, F.; Walzer, C. Comparison of ESBL-And AmpC Producing Enterobacteriaceae and Methicillin-Resistant Staphylococcus aureus (MRSA) Isolated from Migratory and Resident Population of Rooks (Corvus frugilegus) in Austria. PLoS ONE 2013, 8, e84048. [CrossRef] 
17. Jamborova, I.; Janecko, N.; Halova, D.; Sedmik, J.; Mezerova, K.; Papousek, I.; Kutilova, I.; Dolejska, M.; Cizek, A.; Literak, I. Molecular characterization of plasmid-mediated AmpC beta-lactamase- and extended-spectrum beta-lactamase-producing Escherichia coli and Klebsiella pneumoniae among corvids (Corvus brachyrhynchos and Corvus corax) roosting in Canada. FEMS Microbiol. Ecol. 2018, 94. [CrossRef]

18. Dorado-García, A.; Smid, J.H.; van Pelt, W.; Bonten, M.J.M.; Fluit, A.C.; Bunt, G.V.D.; Wagenaar, J.A.; Hordijk, J.; Dierikx, C.M.; Veldman, K.T.; et al. Molecular relatedness of ESBL/AmpC-producing Escherichia coli from humans, animals, food and the environment: A pooled analysis. J. Antimicrob. Chemother. 2018, 73, 339-347. [CrossRef] [PubMed]

19. Surveillance of Antimicrobial Resistance in Europe 2018. Available online: https://www.ecdc.europa.eu/en/publications-data/ surveillance-antimicrobial-resistance-europe-2018 (accessed on 2 November 2020).

20. European Centre for Disease Prevention and Control (ECDC) Rates by Country. Available online: https://www.ecdc.europa.eu/ en/antimicrobial-consumption/database/rates-country (accessed on 28 November 2020).

21. Kazmierczak, K.M.; de Jonge, B.L.M.; Stone, G.G.; Sahm, D.F. In vitro activity of ceftazidime/avibactam against isolates of Enterobacteriaceae collected in European countries: INFORM global surveillance 2012-15. J. Antimicrob. Chemother. 2018, 73, 2782-2788. [CrossRef]

22. Vingopoulou, E.I.; Siarkou, V.I.; Batzias, G.; Kaltsogianni, F.; Sianou, E.; Tzavaras, I.; Koutinas, A.; Saridomichelakis, M.N.; Sofianou, D.; Tzelepi, E.; et al. Emergence and maintenance of multidrug-resistant Escherichia coli of canine origin harbouring a blaCMY-2-IncI1/ST65 plasmid and topoisomerase mutations. J. Antimicrob. Chemother. 2014, 69, 2076-2080. [CrossRef] [PubMed]

23. Liakopoulos, A.; Betts, J.; la Ragione, R.; van Essen-Zandbergen, A.; Ceccarelli, D.; Petinaki, E.; Koutinas, C.K.; Mevius, D.J. Occurrence and characterization of extended-spectrum cephalosporin-resistant Enterobacteriaceae in healthy household dogs in Greece. J. Med. Microbiol. 2018, 67, 931-935. [CrossRef] [PubMed]

24. Investigation of Antimicrobial Resistance Patterns in Commensal Escherichia coli Isolates from Broilers in Greece. Available online: http: / / ecvmicro.org/Files/ICECVM_2019_Abstract_Book_ver3.pdf\#page=119 (accessed on 11 January 2021).

25. Apostolakos, I.; Mughini-Gras, L.; Fasolato, L.; Piccirillo, A. Assessing the occurrence and transfer dynamics of ESBL/pAmpCproducing Escherichia coli across the broiler production pyramid. PLoS ONE 2019, 14, e0217174. [CrossRef] [PubMed]

26. Maamar, E.; Hammami, S.; Alonso, C.A.; Dakhli, N.; Abbassi, M.S.; Ferjani, S.; Hamzaoui, Z.; Saidani, M.; Torres, C.; Boubaker, I.B.-B. High prevalence of extended-spectrum and plasmidic AmpC beta-lactamase-producing Escherichia coli from poultry in Tunisia. Int. J. Food Microbiol. 2016, 231, 69-75. [CrossRef] [PubMed]

27. Päivärinta, M.; Latvio, S.; Fredriksson-Ahomaa, M.; Heikinheimo, A. Whole genome sequence analysis of antimicrobial resistance genes, multilocus sequence types and plasmid sequences in ESBL/AmpC Escherichia coli isolated from broiler caecum and meat. Int. J. Food Microbiol. 2020, 315, 108361. [CrossRef] [PubMed]

28. Aslantaş, Özkan High occurrence of CMY-2-type beta-lactamase-producing Escherichia coli among broiler flocks in Turkey. Trop. Anim. Heal. Prod. 2019, 52, 1681-1689. [CrossRef]

29. Maciuca, I.E.; Williams, N.J.; Tuchilus, C.; Dorneanu, O.; Guguianu, E.; Carp-Carare, C.; Rimbu, C.; Timofte, D. High Prevalence of Escherichia coli-Producing CTX-M-15 Extended-Spectrum Beta-Lactamases in Poultry and Human Clinical Isolates in Romania. Microb. Drug Resist. 2015, 21, 651-662. [CrossRef] [PubMed]

30. Murphy, D.; Ricci, A.; Auce, Z.; Beechinor, J.G.; Bergendahl, H.; Breathnach, R.; Bureš, J.; da Silva, J.P.D.; Hederová, J.; Hekman, P.; et al. EMA and EFSA Joint Scientific Opinion on measures to reduce the need to use antimicrobial agents in animal husbandry in the European Union, and the resulting impacts on food safety (RONAFA). EFSA J. 2017, 15, e04666. [CrossRef] [PubMed]

31. Dorado-García, A.; Mevius, D.J.; Jacobs, J.J.H.; van Geijlswijk, I.M.; Mouton, J.W.; Wagenaar, J.A.; Heederik, D.J. Quantitative assessment of antimicrobial resistance in livestock during the course of a nationwide antimicrobial use reduction in the Netherlands. J. Antimicrob. Chemother. 2016, 71,3607-3619. [CrossRef]

32. Huijbers, P.M.; Graat, E.A.; van Hoek, A.H.; Veenman, C.; de Jong, M.C.; van Duijkeren, E. Transmission dynamics of extendedspectrum $\beta$-lactamase and AmpC $\beta$-lactamase-producing Escherichia coli in a broiler flock without antibiotic use. Prev. Veter. Med. 2016, 131, 12-19. [CrossRef]

33. Nilsson, O.; Börjesson, S.; Landén, A.; Bengtsson, B. Vertical transmission of Escherichia coli carrying plasmid-mediated AmpC (pAmpC) through the broiler production pyramid. J. Antimicrob. Chemother. 2014, 69, 1497-1500. [CrossRef]

34. Jamborova, I.; Dolejska, M.; Vojtech, J.; Guenther, S.; Uricariu, R.; Drozdowska, J.; Papousek, I.; Pasekova, K.; Meissner, W.; Hordowski, J.; et al. Plasmid-Mediated Resistance to Cephalosporins and Fluoroquinolones in Various Escherichia coli Sequence Types Isolated from Rooks Wintering in Europe. Appl. Environ. Microbiol. 2014, 81, 648-657. [CrossRef]

35. Sen, K.; Berglund, T.; Soares, M.A.; Taheri, B.; Ma, Y.; Khalil, L.; Fridge, M.; Lu, J.; Turner, R.J. Antibiotic Resistance of E. coli Isolated from a Constructed Wetland Dominated by a Crow Roost, With Emphasis on ESBL and AmpC Containing E. coli. Front. Microbiol. 2019, 10, 1034. [CrossRef]

36. Jamborova, I.; Dolejska, M.; Zurek, L.; Townsend, A.K.; Clark, A.B.; Ellis, J.C.; Papousek, I.; Cizek, A.; Literak, I. Plasmid-mediated resistance to cephalosporins and quinolones in Escherichia coli from American crows in the USA. Environ. Microbiol. 2017, 19, 2025-2036. [CrossRef]

37. Alcalá, L.; Alonso, C.A.; Simón, C.; González-Esteban, C.; Orós, J.; Rezusta, A.; Ortega, C.; Torres, C. Wild Birds, Frequent Carriers of Extended-Spectrum $\beta$-Lactamase (ESBL) Producing Escherichia coli of CTX-M and SHV-12 Types. Microb. Ecol. 2015, 72, 861-869. [CrossRef] 
38. Poirel, L.; Potron, A.; de la Cuesta, C.; Cleary, T.; Nordmann, P.; Munoz-Price, L.S. Wild Coastline Birds as Reservoirs of Broad-Spectrum- $\beta$-Lactamase-Producing Enterobacteriaceae in Miami Beach, Florida. Antimicrob. Agents Chemother. 2012, 56, 2756-2758. [CrossRef]

39. Poirel, L.; Decousser, J.-W.; Nordmann, P. Insertion Sequence ISEcp1B Is Involved in Expression and Mobilization of a blaCTX-M $\beta$-Lactamase Gene. Antimicrob. Agents Chemother. 2003, 47, 2938-2945. [CrossRef]

40. Saladin, M.; Cao, V.T.B.; Lambert, T.; Donay, J.-L.; Herrmann, J.-L.; Ould-Hocine, Z.; Verdet, C.; Delisle, F.; Philippon, A.; Arlet, G. Diversity of CTX-M $\hat{~}^{2}$-lactamases and their promoter regions fromEnterobacteriaceaeisolated in three Parisian hospitals. FEMS Microbiol. Lett. 2002, 209, 161-168. [CrossRef]

41. Koga, V.L.; Maluta, R.P.; Da Silveira, W.D.; Ribeiro, R.A.; Hungria, M.; Vespero, E.C.; Nakazato, G.; Kobayashi, R.K.T. Characterization of CMY-2-type beta-lactamase-producing Escherichia coli isolated from chicken carcasses and human infection in a city of South Brazil. BMC Microbiol. 2019, 19, 1-9. [CrossRef]

42. Nicolas-Chanoine, M.-H.; Blanco, J.; Leflon-Guibout, V.; Demarty, R.; Alonso, M.P.; Caniça, M.M.; Park, Y.-J.; Lavigne, J.-P.; Pitout, J.; Johnson, J.R. Intercontinental emergence of Escherichia coli clone O25:H4-ST131 producing CTX-M-15. J. Antimicrob. Chemother. 2007, 61, 273-281. [CrossRef]

43. Pitout, J.D.; Finn, T.J. The evolutionary puzzle of Escherichia coli ST131. Infect. Genet. Evol. 2020, 81, 104265. [CrossRef] [PubMed]

44. Lazarus, B.; Paterson, D.L.; Mollinger, J.L.; Rogers, B.A. Do Human Extraintestinal Escherichia coli Infections Resistant to ExpandedSpectrum Cephalosporins Originate from Food-Producing Animals? A Systematic Review. Clin. Infect. Dis. 2015, 60, 439-452. [CrossRef] [PubMed]

45. Foster-Nyarko, E.; Alikhan, N.-F.; Ravi, A.; Thomson, N.M.; Jarju, S.; Kwambana-Adams, B.A.; Secka, A.; O'Grady, J.; Antonio, M.; Pallen, M.J. Genomic diversity of Escherichia coli isolates from backyard chickens and guinea fowl in the Gambia. Microb. Genom. 2021, 7, mgen000484. [CrossRef]

46. Papouskova, A.; Masarikova, M.; Valcek, A.; Senk, D.; Cejkova, D.; Jahodarova, E.; Cizek, A. Genomic analysis of Escherichia coli strains isolated from diseased chicken in the Czech Republic. BMC Veter. Res. 2020, 16, 1-10. [CrossRef] [PubMed]

47. Xu, J.; Lin, W.; Chen, Y.; He, F. Genomic and phylogenetic analysis of a community-acquired extended-spectrum $\beta$-lactamaseproducing Escherichia coli ST429 strain recovered from a urinary tract infection. J. Glob. Antimicrob. Resist. 2020, 22, 656-658. [CrossRef] [PubMed]

48. Maluta, R.P.; Logue, C.M.; Casas, M.R.T.; Meng, T.; Guastalli, E.A.L.; Rojas, T.C.G.; Montelli, A.C.; Sadatsune, T.; Ramos, M.D.C.; Nolan, L.K.; et al. Overlapped Sequence Types (STs) and Serogroups of Avian Pathogenic (APEC) and Human Extra-Intestinal Pathogenic (ExPEC) Escherichia coli Isolated in Brazil. PLoS ONE 2014, 9, e105016. [CrossRef]

49. Hall, M.L.-V.; Dierikx, C.; Stuart, J.C.; Voets, G.; Munckhof, M.V.D.; van Essen-Zandbergen, A.; Platteel, T.; Fluit, A.; van de Sande-Bruinsma, N.; Scharinga, J.; et al. Dutch patients, retail chicken meat and poultry share the same ESBL genes, plasmids and strains. Clin. Microbiol. Infect. 2011, 17, 873-880. [CrossRef]

50. Manges, A.R.; Harel, J.; Masson, L.; Edens, T.J.; Portt, A.; Reid-Smith, R.J.; Zhanel, G.G.; Kropinski, A.M.; Boerlin, P. Multilocus Sequence Typing and Virulence Gene Profiles Associated with Escherichia coli from Human and Animal Sources. Foodborne Pathog. Dis. 2015, 12, 302-310. [CrossRef]

51. Roth, N.; Käsbohrer, A.; Mayrhofer, S.; Zitz, U.; Hofacre, C.; Domig, K.J. The application of antibiotics in broiler production and the resulting antibiotic resistance in Escherichia coli: A global overview. Poult. Sci. 2019, 98, 1791-1804. [CrossRef]

52. Sheikh, A.A.; Checkley, S.; Avery, B.; Chalmers, G.; Bohaychuk, V.; Boerlin, P.; Reid-Smith, R.; Aslam, M. Antimicrobial Resistance and Resistance Genes in Escherichia coli Isolated from Retail Meat Purchased in Alberta, Canada. Foodborne Pathog. Dis. 2012, 9 , 625-631. [CrossRef]

53. Ahmed, A.M.; Shimamoto, T.; Shimamoto, T. Molecular characterization of multidrug-resistant avian pathogenic Escherichia coli isolated from septicemic broilers. Int. J. Med. Microbiol. 2013, 303, 475-483. [CrossRef]

54. Navia, M.A. A Chicken in Every Pot, Thanks to Sulfonamide Drugs. Science 2000, 288, 2132-2133. [CrossRef] [PubMed]

55. Diarra, M.S.; Silversides, F.G.; Diarrassouba, F.; Pritchard, J.; Masson, L.; Brousseau, R.; Bonnet, C.; Delaquis, P.; Bach, S.; Skura, B.J.; et al. Impact of Feed Supplementation with Antimicrobial Agents on Growth Performance of Broiler Chickens, Clostridium perfringens and Enterococcus Counts, and Antibiotic Resistance Phenotypes and Distribution of Antimicrobial Resistance Determinants in Escherichia coli Isolates. Appl. Environ. Microbiol. 2007, 73, 6566-6576. [CrossRef] [PubMed]

56. Marcelino, V.R.; Wille, M.; Hurt, A.C.; González-Acuña, D.; Klaassen, M.; Schlub, T.E.; Eden, J.-S.; Shi, M.; Iredell, J.R.; Sorrell, T.C.; et al. Meta-transcriptomics reveals a diverse antibiotic resistance gene pool in avian microbiomes. BMC Biol. 2019, 17, 1-11. [CrossRef]

57. Ecanton, R.; Egonzalez-Alba, J.M.; Egalán, J.C. CTX-M Enzymes: Origin and Diffusion. Front. Microbiol. 2012, 3, 110. [CrossRef]

58. Mavroidi, A.; Miriagou, V.; Liakopoulos, A.; Tzelepi, E.; Stefos, A.; Dalekos, G.N.; Petinaki, E. Ciprofloxacin-resistant Escherichia coli in Central Greece: Mechanisms of resistance and molecular identification. BMC Infect. Dis. 2012, 12, 371. [CrossRef] [PubMed]

59. Baez, M.; Espinosa, I.; Collaud, A.; Miranda, I.; Montano, D.; Feria, A.; Hernández-Fillor, R.; Obregón, D.; Alfonso, P.; Perreten, V. Genetic Features of Extended-Spectrum $\beta$-lactamase-Producing Escherichia coli from Poultry in Mayabeque Province, Cuba. Antibiot. 2021, 10, 107. [CrossRef] [PubMed]

60. Oh, J.-Y.; Kwon, Y.K.; Tamang, M.D.; Jang, H.-K.; Jeong, O.-M.; Lee, H.-S.; Kang, M.-S. Plasmid-Mediated Quinolone Resistance in Escherichia coli Isolates from Wild Birds and Chickens in South Korea. Microb. Drug Resist. 2016, 22, 69-79. [CrossRef] [PubMed] 
61. Réglier-Poupet, H.; Naas, T.; Carrer, A.; Cady, A.; Adam, J.-M.; Fortineau, N.; Poyart, C.; Nordmann, P. Performance of chromID ESBL, a chromogenic medium for detection of Enterobacteriaceae producing extended-spectrum $\beta$-lactamases. J. Med. Microbiol. 2008, 57, 310-315. [CrossRef] [PubMed]

62. The European Committee on Antimicrobial Susceptibility Testing. Breakpoint Tables for Interpretation of MICs and Zone Diameters, Version 10.0; European Committee on Antimicrobial Susceptibility Testing: Växjö, Sweden, 2020; pp. 1-77.

63. Pérez-Pérez, F.J.; Hanson, N.D. Detection of Plasmid-Mediated AmpC-Lactamase Genes in Clinical Isolates by Using Multiplex PCR. J. Clin. Microbiol. 2002, 40, 2153-2162. [CrossRef]

64. Li, Q.; Sherwood, J.; Logue, C. Characterization of antimicrobial resistant Escherichia coli isolated from processed bison carcasses. J. Appl. Microbiol. 2007, 103, 2361-2369. [CrossRef] 